\title{
Application of Total Quality Services to Increase Non-Formal Education Institution Capacity in Kampung Inggris Kediri
}

\author{
Rinto Alexandro \\ Faculty of Teacher Training and Education \\ University of Palangka Raya, Central Kalimantan Indonesia \\ Email: rintoalexandro76@gmail.com
}

\begin{abstract}
The objective of this study is to obtain a fixed model that can be applied in the framework of capacity building of course institutions through meeting national standards for non-formal education, accreditation registration, and the application of total quality service. This research method is action research ranging from the formation of teams per area \& Need assessment, data processing of the needs assessment survey, socialization and training, facilitation of 20 course institutions to be registered for institutional accreditation to National Accreditation Board for Early Childhood Education and Non-Formal Education (BAN-PAUD-PNF), assistance to thin management institutions in prepare accreditation and implementation of TQS, explore cooperation with BAN-PAUD-PNF in Jakarta. Based on the results of data analysis it can be concluded: 1) to increase the capacity of course institutions it is necessary to improve quality through accreditation of institutions from official state institutions, ISOs, and from the application of total quality service management (TQS). Through institutional accreditation, it will be able to increase public confidence in the existing course institutions. Likewise with ISO, will be able to increase public confidence, that the institution has implemented good management.
\end{abstract}

Key words: capacity, institution, education, non-formal, total quality service

\section{INTRODUCTION}

There are a large number of English language institutions in Pare Kediri, East Java, and the majority have not met the demands of national non-formal education standards (SN-PNF) as evidenced by the majority of being "not accredited" by the National Accreditation Agency for Early Childhood Education and Non-formal Education (BAN- PAUD-PNF), so they have not been able to provide quality assurance to service users. The majority of English language institutes in Pare are also the majority not yet implementing total quality service (TQS) in providing services to students who use their services. Therefore, through this research a model of capacity building for national standard course institutions is developed through accreditation, and total quality service, so that existing course institutions become ready to compete with other course institutions. 
In this era of global competition, the educational trend is experiencing a shift in orientation that places complete human development through education and training, with various types, traits, levels and various forms of skill fields. Therefore, the establishment of Institute of Courses and Training (LKP) is one of the answers to the needs of the community today, as explained in Law No. 20 of 2003 Article 26 point 5 that "Courses and training are held for people who need knowledge, skills, life skills, and attitudes to develop themselves, develop the profession, work, independent business, and / or continue their education to a higher level ".

Efforts to produce individuals who excel at LKP institutions continue to strive to find the right formula, so that LKP institutions are used as instruments in preparing the best quality graduates. However, LKP institutions also have a big role in the issue of the quality of graduates, so the emphasis on the quality of professional LKP institutions is always expected by the Government and the community.

LKPs in English Village are located in Singgahan Village and Tulungrejo Village, Pare Kediri District, East Java. It took three hours by road from Surabaya. As many as $95 \%$ of the population in the English Village uses Javanese. Kampung Inggris is a village with more than 100 language courses. Therefore, it is more appropriate as a village/language village. The learning system in the English Village is more directed towards conventional learning systems. The emphasis is on discipline, intensity of learning and a very supportive environment. More than 1000 people every month come with one goal, learn English.

Kampung Pare is a traditional village that daily uses regional languages and is thick with Javanese customs. Many community activities nuanced Islamic and there are Islamic boarding schools around Kampung Pare. Tolerance of social life, prioritizing norms and laws, manners and manners are still heavily guarded in Pare.

The basic problems faced by English language courses in Pare Kediri can be identified as follows.

First, the number of English language institutions in Pare Kediri, East Java is large, and the majority have not been accredited by the National Accreditation Board for Non-Formal Children Education (BAN-PAUD-PNF), so they have not been able to provide quality assurance to service users.

Secondly, the majority of English Language Institutions in Pare Kediri have not fulfilled the eight national Non-formal education standards which include content standards, process standards, graduation standards, facilities and infrastructure standards, teaching and educational staff standards, management standards, cost standards, and assessment standards.

Third, the majority of courses in Pare have not been able to evaluate themselves. As it is known that self-evaluation is a systematic effort to collect, select and obtain valid data and information from the facts carried out by the relevant course institution, so that a comprehensive picture of the state of the course institution can be used to take management actions for the development of course institutions. The purpose of selfevaluation is to obtain objective, transparent and accountable information from the institution itself. 
Fourth, the majority of the existing institute courses in Pare have not implemented total quality service in providing services to their students who use their services. Therefore, through this research, a model of capacity building for institution institutions is developed through accreditation and the application of total quality service, so that existing institutions become ready to compete with other course institutions.

Considering the above problems, it is felt very important to conduct research on the development of institutional capacity building models for national level cursors through accreditation and application of TQS, so as to create a course institution capable of providing excellent service and be able to compete at the local, national, regional, and international levels.

The purpose of this study is to produce: (1) a model of increasing the capacity of course institutions so that they are competitive with a variety of other course institutions, (2) obtaining recommendations for education offices, local governments, and tertiary institutions in order to increase the capacity of English language course institutions promoting local and regional competitiveness, and (3) new theories relating to the capacity building model of a strong institution so that it is highly competitive in dealing with the AEC.

The urgency of this research is expected to: (1) find a model for improving the capacity of fixed English course institutions that can be input for policy makers and regulations for institutional capacity building through accreditation, trademark registration, and service management quality improvement based on total quality service (TQS) so that it has high output and competitiveness, (2) making theoretical contributions in social science, especially institutional strengthening; (3) able to give birth to a new innovation about the capacity building model of the institution, and (3) find new theories that can strengthen or strengthen the results of previous research.

Quality control (quality control) in quality management is a system of routine technical activities designed to measure and assess the quality of products or services provided to customers. Quality control in non-formal education programs is needed so that the quality of non-formal education service products is maintained so as to satisfy the community as customers. The accreditation of non-formal education institutions conducted by BAN-PAUD-PNF becomes strategic because it has the main function as controlling the quality of non-formal education units.

Control is needed in the management of education quality to ensure that education services are in accordance with predetermined plans, so that the products produced are in accordance with customer expectations. Quality control is very close to quality control activities, whereas quality control is an effort to keep the activities carried out according to plan and produce output in accordance with established standards.

Ishikawa (1995) states that quality control is the implementation of steps that have been planned in a controlled manner so that everything takes place as it should, so that the quality of the planned product can be achieved and guaranteed. In Ishikawa's understanding it is also implied that quality control is carried out with an orientation on 
customer satisfaction. In the language of non-formal education services the whole process organized by the non-formal education unit is aimed at meeting the needs of the community as consumers.

In line with the concept of quality control above. Control over the quality of non-formal education does involve elements of input, process and output. Therefore, in controlling the quality of non-formal education, non-formal education institutions must meet eight national education standards, namely the content standards, process standards, graduation standards, facilities and infrastructure standards, management standards, cost standards, and assessment standards. Thus in carrying out quality control, BAN-PNF sees education units or educational processes as a system. This means that quality control should be carried out continuously and sustainably

Accreditation is an activity for evaluating the feasibility of a program in an education unit based on established criteria. Accreditation aims to: (a) determine the level of eligibility of a Non-formal education institution in providing educational services and (b) obtain an overview of the performance of Non-formal educational institutions

The National Accreditation Board for Early Childhood Education and NonFormal Education (BAN-PAUD-PNF) is: a non-structural body that is technically independent and professional consisting of elements of society, educational organizing organizations, higher education institutions, and relevant organizations who has the authority to establish policies, standards, systems and tools for national accreditation.

The function of accreditation of non-formal education institutions is: (a) for knowledge, namely in order to find out how the feasibility \& performance of nonformal education institutions is seen from various related elements, (b) for accountability, namely so that non-formal educational institutions can be held responsible for whether the services provided meet expectations or the desire of the community, and (c) for the benefit of development, namely so that non-formal educational institutions can improve quality or development based on input from the results of accreditation.

The principles of accreditation of Non-formal education institutions are: (a) objective, objective information about the feasibility and performance of Non-formal education institutions, (b) effective, the results of accreditation provide information that can be used as a basis for decision making, (c) comprehensive, covering various aspects and comprehensive, (d) independent, Non-formal education institutions can strive to improve quality by reflecting on self-evaluation, and (d) mandatory, accreditation is carried out for each Non-formal educational institutions in accordance with the readiness of Non-formal educational institutions.

The accreditation system has the following characteristics: (a) a balance of focus between school eligibility and performance, (b) a balance between internal and external assessments, and (c) a balance between formal ranking of course institutions and feedback on improvement.

Kotler \& Keller (2006:25) also revealed that: "A company has succeeded in offering products / services to customers if it is able to provide value and satisfaction." 
Value is the customer's estimation of all products' ability to satisfy their needs. "Broadly speaking, customer value is the ratio between the perceived benefits of a product and the costs incurred to obtain the product. To get customer value that is in accordance with customer perceptions, then a company must always follow it by providing the appropriate product / service, because customer value is always changing all the time.

Monroe in Vanessa (2007:65) states that customer value is the ratio between benefits or perceived benefits and sacrifices incurred. Where the perceived benefits are a combination of physical attributes, service attributes and supporting techniques in product utilization. Sacrifices incurred are the total costs incurred by consumers including purchase costs and additional costs (such as ordering, transportation, installation, order handling costs) as well as out-of-purchase costs (replacing damage, risk of failure or poor service).

Buchari (2007:295) states that customer value is the difference between the total value added obtained by consumers compared with the total costs incurred.

According to Kotler \& Keller (2006:136), "total quality service" is "giving service to customers in total so that this is also an effort to create satisfied customers". That is, that to be able to maintain its survival, a company must have consumers who feel happy and satisfied with the products offered. Excellent Service (Excellent Service / Customer Care) literally means excellent service, or the best service. Excellent Service (Customer Care) is a key factor in the company's success. If a business grows and develops and continues to be used to survive in competition, profits and revenues must also increase.

Excellent Service (Customer Care) means maintaining and maintaining our customers and adding new customers. Many aspects can provide customer satisfaction and not just give the best. In the current free market era, many are offered only quality goods, but an ongoing and continuous relationship between sellers and customers has not been well considered. Good service (Customer care) is needed by all members of the company, without exception. Whether they are dealing directly with customers or not, carrying out tasks by working with others, it takes confidence to adjust and consider the trust and secrets of customers in us.

Excellent service (Customer care) is not just about providing a service, it requires a little extra service and in accordance with the expectations of customers who expect the best service. This means making employees who work in the company make the right choices, steps, attitudes in dealing with customers.

\section{METHODS}

The research model used is model development research. The development of the model begins with the preparation of a draft model based on the results of previous research and existing theories, followed by a community need assessment (data collection), data collection, and analysis of model test data using assessment data that has been done. The study was conducted in Singgahan Village and Tulungrejo Village, Pare Kediri District, East Java. Research Time Begins June s.d. November 2016. 
Primary data was collected using participatory observation techniques, and indepth interviews. In addition, measurements were made between before and after the counseling action the importance of following the accreditation program, the application of TQS, and guidance on filling out self-evaluation forms in the framework of accreditation, and counseling about good office management.

In order to obtain secondary data, documentation techniques were used both from the village head's office, the Kediri district education office, the Tourism Office, and from other relevant parties. Qualitative data obtained using participatory observation techniques and in-depth interviews were analyzed using a four-step qualitative data analysis technique which included data collection, data reduction, data classification, and drawing conclusions (Basrowi \& Suwandi, 2008).

\section{RESULT AND DISCUSSION}

To get the right model, we use the model development flowchart with the following steps. 


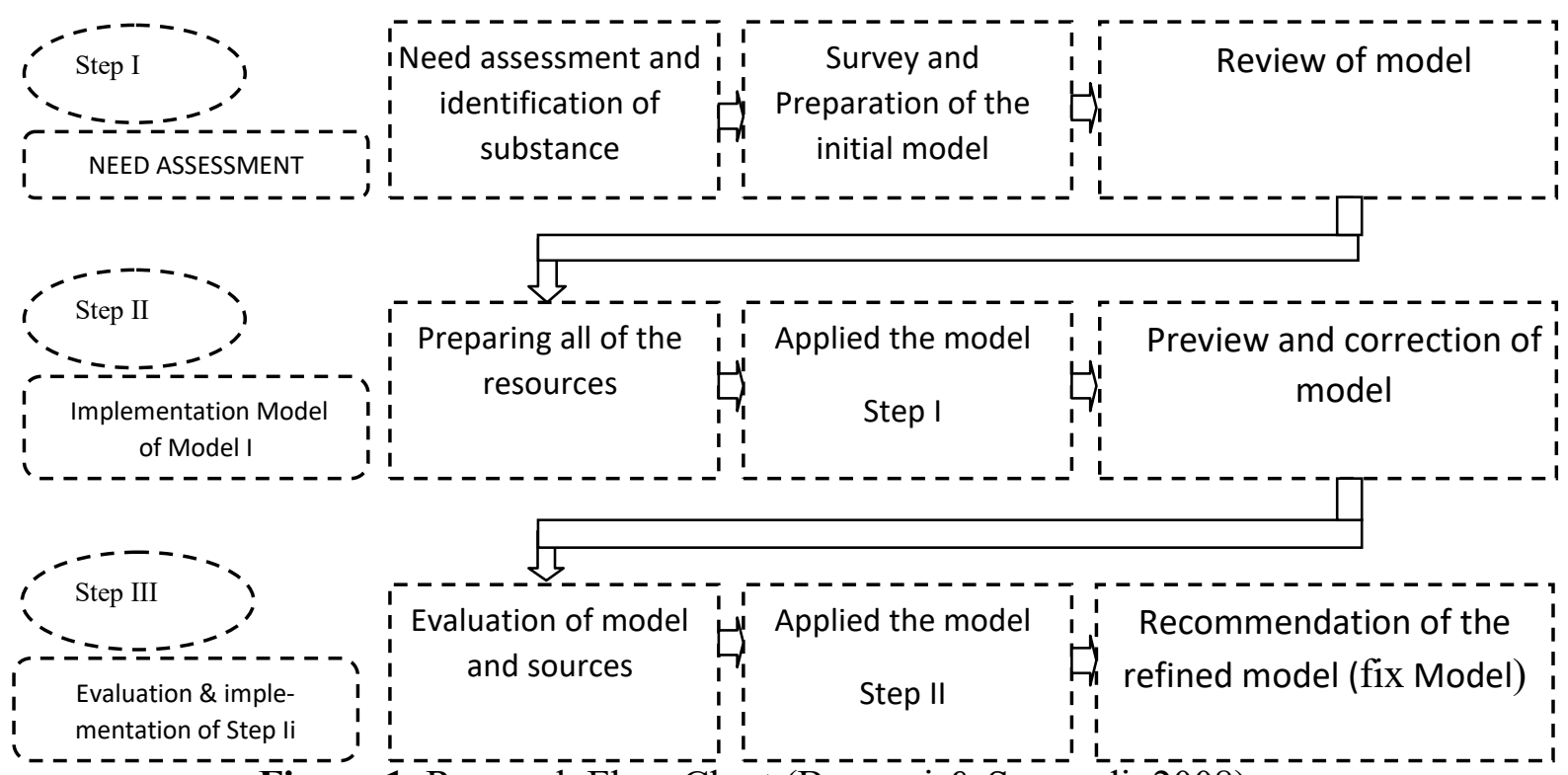

Figure 1. Research Flow Chart (Basrowi \& Suwandi, 2008)

Phase 1 was carried out as follows: Conducting research preparation, coordinating with the research team and forming a research assistant team, survey needs assessment, in-depth interviews, and participatory observation, Conducting socialization, counseling, coaching, and training, Facilitating the management of the course institute to discuss in filling out the forms of self-evaluation in the context of accreditation, and the implementation of TQS, Assistance to the management of course institutions, Exploring cooperation with BAN-PAUD-PNF and embassies that use English to want to be a native speaker

In the second phase of research, the researcher conducted: Preparing for the application of the stage I model, Applying the stage I model, Monitoring and evaluating the progress of the implementation of phase I, Increasing the number of course institutions implementing TQS and following the institution's accreditation program, Conducting discussions on the weaknesses of the application of the stage I model with experts and related practitioners, Developing a network of cooperation both with BANPAUD- PNF and embassies that use English to want to be a native speaker, Hold a Focus Group Discussion, and prepare a draft report

In the third phase of the research, the researcher undertook: preparation for improving resources in the framework of applying the Phase II model, applying the Phase II model, monitoring and evaluating (monitoring evaluation), increasing the number of accredited course institutions and implementing TQS, holding discussions on the weaknesses of the application of the Phase II model with relevant experts and 
practitioners, expanding cooperation networks, and compiling international manuscripts and journals.

This research has been carried out for twelve months in August 2018 until August 2019. All stages have been passed from the formation of a research team, actions, evaluations, data collection, data analysis, to drawing conclusions. In the process of forming the team, the researcher has held a FGD for all team members to equalize the perception, so that during the implementation in the field there was no mistake.

Based on research data it can be seen that, quality assurance in the form of institutional accreditation can improve the quality of institutions. In addition, the institution has become more trusted by the public. The community is more confident, if the English course at an accredited institution, the quality will be better than attending courses at an institution that has not been accredited. The community also feels that the course institutions that are followed are quality institutions, because they have been accredited by government accreditation agencies.

As it is known that, the accreditation process is a process of quality assurance from the State party to course institutions in Indonesia, in order to provide protection and guarantee to the public. The state must provide guarantees that the quality of course institutions providing skills education services to the community must be recognized in the form of accreditation.

Accreditation can also be interpreted as a form of guarantee from course institutions, even if the educational process is carried out in accordance with national standards, which include the content standards (curriculum standards), process standards, management standards, human resource standards, facilities and infrastructure standards, funding standards, assessment standards.

Institutions that have obtained ISO certificates for good management also position the educational institutions as well. Evidently their management has been recognized by international certifying institutions. As is known, international certification institutions will not be careless or careless in providing certificates, because they have carried out the verification, verification, clarification, and validation of all physical data and field data owned by the course institutions.

An institution that has received an ISO certificate is also said to have been able to provide accountability to customers, users, and the community in general. ISO granting institutions can be ensured that their performance has been standardized, in accordance with standard operating procedures (POS). a course institution that already has an ISO can be sure that, in the management of management starting from planning, organizing, implementing, and evaluating, all of them have used established standards.

Course institutions that provide total quality service also provide significant results for the development of the number of students studying at these course institutions. the community currently has a good understanding of the existing course institutions. The community no longer believes in the existing course institutions, and the community only believes in the course institutions which have actually implemented the total quality service well. 
Course institutions that have done a maximum total quality service, will be able to increase the satisfaction of the community users of the course institutions. a high level of community satisfaction will give a very good impression that can be shared with others. The process is the most effective advertising. Therefore, course institutions that do not carry out total quality service on a continuous progress basis will be left by consumers. Especially in this era of social media, if there is a course that is not good, because it does not implement total quality service, it will be spread secretly through social media in hand. It will have a very big negative impact, and will turn off the course institution in the future.

Another step that has been taken by researchers together with the institute of courses that are the target of research has been collaborating with the local government in this case the education office of the City of Kediri, to continue to provide guidance and supervision to the institution to always improve its quality. This was done to provide services to the community, that the course institutions that every day provide English language training to the general public, can provide the best service.

Another step that has also been taken by researchers is to conduct internal coaching to all course institutions to make the association of course institutions so that they can become sturdy institutions. With the union formed in the association, the existing course institutions can channel their aspirations, through the association to be conveyed to related parties so that the course institutions' voices are more heard by stakeholders. If in submitting an opinion or proposal to the government made by a single vote, of course it will not be heard. It is different if the demands submitted to the government or other parties are made through forums or associations. The entire description above, if realized in the form of a model diagram will appear in diagram 2.

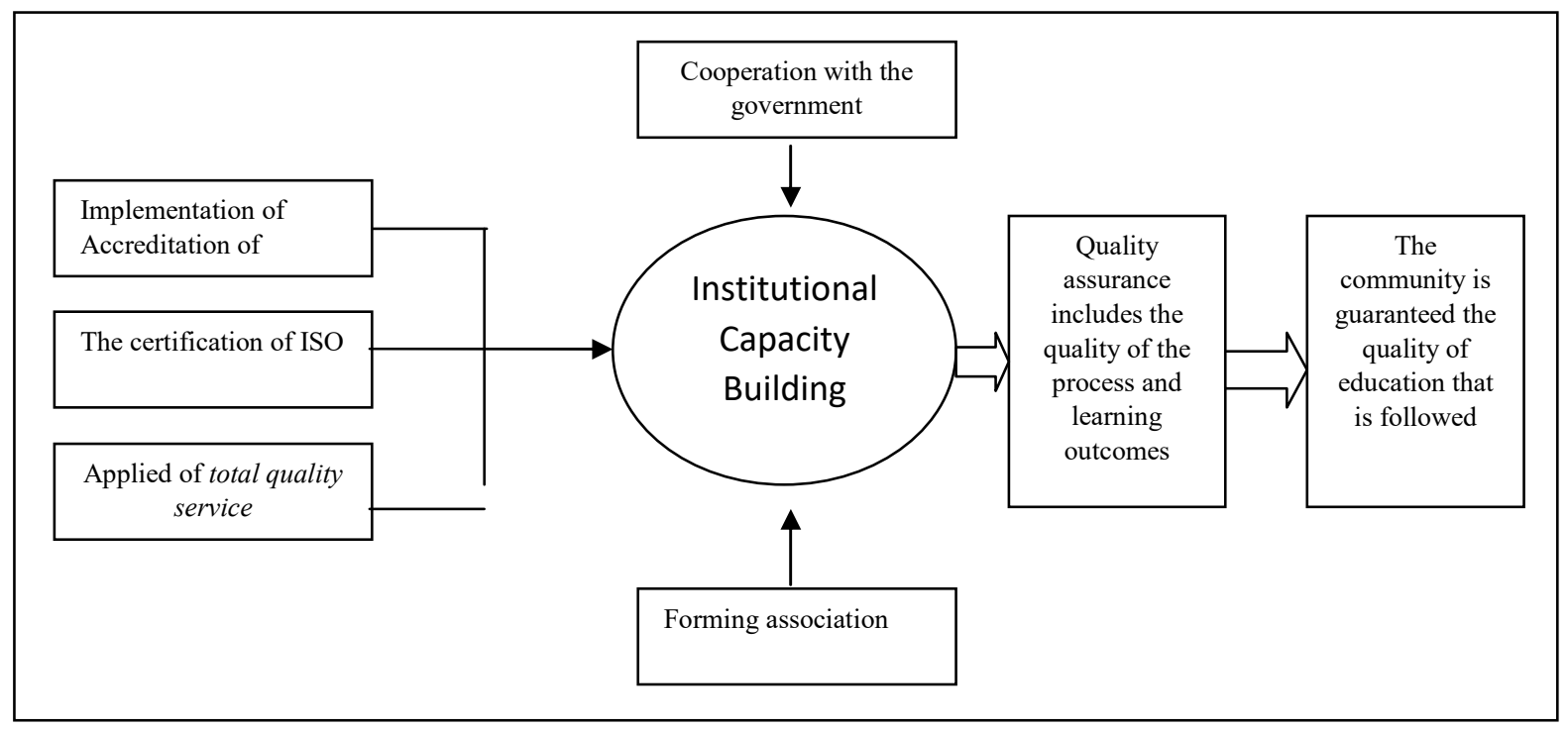


Figure 2: Model of Capacity Building for Institution Courses in order to protect the interests of the community

In fact, creating these customers is not easy. The company needs a product that has a value that is in accordance with the prevailing customer value perception. In addition the company faces its own challenges in dealing with consumers, because at this time consumers can more freely choose products, brands, and manufacturers that are in accordance with their needs and desires. For this reason, companies compete with each other to provide the highest value for consumers, because consumers want the maximum value limited by search costs, limited knowledge, mobility, and income. The greater the benefits provided compared to the price, the greater the value obtained by the customer for the product.

Among the superior values that customers receive come from the superior quality of the product. This means that the quality of the product exceeds the quality of other similar products. Superior quality will be felt by the market if it is communicated with the market.

Companies must be able to understand the needs of consumers they formulate well, as well as having an effective design and quality control of the products they make. If both are carried out well, then superior quality can be created in the minds of customers, thus getting an impression of good quality in the market. To improve the impression of quality, one can be created by advertising and other marketing communications, as well as cost advantages. If the customer has a good quality impression, the value obtained by the customer through the product will be high, so the company has high profitability, growth, and market share.

The results of a study conducted by Cucu Sukmana and Dian Dwi Lestari (2013) show that the indicator of the availability of course education services is the national student ratio per institution of 104 meaning that 1 LPK accommodates 104 students. The ratio of students per educator nationally is 16 . The high ratio of students per educator can have an impact on the ineffectiveness of the learning process. The ratio of educators per institution nationally is 7 . High or low ratio of educators per institution can affect the quality of the course because the institution will not run effectively if Human Resources (HR) in the institution experiences shortages. In the indicator of course service quality, the percentage of national course graduates was $64.21 \%$ where $44.44 \%$ of graduates were male and $55.56 \%$ of graduates were female. From this data it is known that 15 provinces are above the provincial figure and there are still 18 provinces below the national number. Based on the analysis of the data mentioned above, what underlies the number of female graduates to men includes: 1) the interest in the course program is more desirable by women than for men, 2) the group of skills courses organized by LKP are based more on skills.

Rabiatul Adawiah (2012) Types of courses held in Balangan Regency are Kumputer, driving and English. Efforts made by course institutions in community empowerment are to provide cost relief (provide discounts and installment fees), extend course time with no additional fees, provide choice of time in accordance with the preoccupations of course participants and organize courses for free. Non-formal 
education is a community effort in finding a solution to the problems of formal education that are not affordable by the community. Attention non-formal education is more focused on efforts to help the realization of the learning process in the community.

Maulia (2014) concluded that based on the results of data analysis using the pooled variant $t$ test, it was obtained that tcount was 1.45 and ttable found 2.010 at an error level of 0.05 or $5 \%$ with this stated that the table was 1.45. Researcher's suggestion for schools is that alternative education that can support learning in the classroom can be used as a school program in improving the quality of learning in schools. For teachers, it should increase mastery of varied and attractive teaching methods and techniques, giving members the same treatment and guidance for students. Whereas for other researchers, it is expected to be able to examine the same thing in depth and detail about the methods and techniques of teaching mathematics using Jarimatika and Abacus, with a broader sample, as well as paying attention to the level or level of learning in Jarimatika and or Abacus.

Nurhandoko (2003) concluded that the factors driving the learning model include a strategic course environment, the interest of the surrounding community strongly supports this activity, the learning media has been improved. While the inhibiting factors consist of learning media not released for learning citizens, differences in background, and limited classrooms. Based on these results, suggestions are given: 1) Managers should collaborate by offering workers who come from graduates of the courses they manage. 2) For the sake of the smooth learning process, the course institution should add class facilities to overcome the imbalance of the number of learning citizens and the number of classrooms.

The results of a study conducted by Ricad Neton Priago (2013) concluded that the learning process at LPK CHINJU had been going well, all students were satisfied, because the learning process proceeded in an orderly, disciplined manner, and the results could immediately be felt for the benefits. LPK CHINJU managers in planning a course program are expected to have tutors who are truly experts in their respective fields, so that the objectives of the course are actually achieved well.

Kurniasari (2014) concluded that: (1) The profile of the students in bridal makeup courses has been archived in accordance with the management requirements of non-formal educational institutions. Learners of bridal makeup courses have different characters and backgrounds and are not distinguished by age, gender, occupation and formal education. There are some students who are not actively participating in the course even though they are registered as students of the bridal makeup course at LKP Sanita; (2) The reason students choose a bridal makeup course is first, to meet the needs that exist in him. These needs are self-actualization, self-esteem, and social needs. This need is in accordance with the reasons students choose bridal makeup courses because of their hobbies, salon recognition, and wanting to look more beautiful. Second, because competent course instructors; (3) The meaning that can be constructed on the grounds that students choose bridal makeup courses as needed to meet expectations. The meaning is to channel a hobby, get a job, improve the economy of the surrounding community, more confidence in relationships, and an increase in skills. Referring to the 
results of the study, it is recommended to: (1) the institute of the course, this research be used as input for institutions for marketing strategies to select potential customers; (2) course instructors, this research can be a course instructor's reference to develop learning according to the needs of students; (3) majoring in non-school education, this research is used as a reference material for students in the identification of needs, especially courses.

Reading all the reports of previous research results, it can be understood that in fact there has been no research on the theme of developing a model of increasing the capacity of course institutions towards a national standard by applying accreditation and applying TQS in rank to improve service quality and competitiveness both nationally and internationally.

\section{CONCLUSION}

Based on the results of data analysis it can be concluded: 1) to increase the capacity of course institutions, it is necessary to improve quality through accreditation of institutions from official state institutions, ISOs, and from the application of total quality service management (TQS); 2) Through the accreditation of institutions, will be able to increase public confidence in the existing course institutions. Likewise with ISO, will be able to increase public confidence, that the institution has implemented good management.

Based on the conclusions above, it can be recommended that all course institutions should maintain quality, by accrediting their institutions, also certifying their institutions through ISO certification, and always improving the quality of institutions by implementing continuous total quality service (continuous progress).

\section{References}

Adawiah, Rabiatul. 2014. Peranan Lembaga Kursus dalam Pemberdayaan Masyarakat Di Kabupaten Balangan. Skripsi. Banjarmasin: Unlam

Alma, Buchari. 2007. Manajemen Pemasaran dan Pemasaran Jasa. Bandung: Alfabeta Basrowi \& Suwandi, 2008. Penelitian Kualitatif. Jakarta: Rineka Cipta

Hosea, Dian. 2015. Konsep Pengendalian Mutu, https://www.academia.edu/5622236/ Kotler \& Keller. 2006. Marketing Manajemen (12nd ed.) Boston: Pearson Prentice Hall, Krisna, N.L. 2016. Menciptakan Pelanggan. http://marketingteori.blogspot.co.id/2007/04

Kurniasari, Yuyun Ika. 2014. Alasan Peserta Didik Memilih Kursus Tata Rias Pengantin (Studi Kasus di LKP Sanita Kabupaten Trenggalek). Skripsi, Jurusan Pendidikan Luar Sekolah, Fakultas Ilmu Pendidikan, Universitas Negeri Malang. Maulia, Nurlaila Novi. 2009. "Perbedaan Hasil Belajar Siswa Kelas IV Yang Mengikuti Kursus Jarimatika dengan Yang Mengikuti Kursus Sempoa Pada Mata pelajaran Matematika Di SD Negeri 3 Rumbuk Lombok Timur”. Skripsi, Jurusan Teknologi Pendidikan, Fakultas Ilmu Pendidikan, Universitas Negeri Malang Morrissey, Vanessa. 2007. Quality control management. Florida: Nortchon.Inc. 
Nurhandoko, Hilyar. 2003. Model Pembelajaran Kursus Komputer Di Lembaga Kursus Adias Sindo Cerdas (ASC) (Studi Kasus Salah Satu Lembaga Kursus Komputer di Jalan Sindoro No. 39 Kabupaten Pemalang). Skripsi. Semarang: Unnes

Priago, Ricad Neton. 2013. Pengelolaan Lembaga Kursus (LPK) Chinju Dalam Menyelenggarakan Kursus Bahasa Korea Di Kota Bengkulu. Skripsi. Bengkulu: Unib

Selfiadhy Putry Anjani, 2015. Memahami Konsep Pelayanan Prima. https://www.facebook.com/permalink

Sukmana, Cucu dan Dian Dwi Lestari. 2013. Analisis Mutu Kursus. Jakarta:

Kemendikbud, Pusat Data Statistik. Bidang Pendayagunaan dan Pelayanan Data dan Statistik Pendidikan.

Tedja, Hendry Zaputra. 2016. Nilai Pelanggan dan Loyalitas Pelanggan. https://hendryza.wordpress 
CENDEKIA, Vol. 14 No. 1 April 2020

p ISSN: 1978 2098; e ISSN: 2407 8557

Https://soloclcs.org; Email: cendekiaoslo@gmail.com

Center of Language and Cultural Studies, Surakarta, Indonesia

Alexandro, Rinto. (2020). Increasing Non Formal Education Institution Capacity

with the Application of Total Quality Services.

Cendekia (2020), 14(1): 63 76. DOI: 10.30957/cendekia.v14i1.611. 